\title{
MECHANICAL PROPERTIES OF NIOBIUM RADIO-FREQUENCY CAVITIES
}

\author{
G. Ciovati $^{\text {a.*1 }}$, P. Dhakal ${ }^{\mathrm{a}}$, J. Matalevich ${ }^{\mathrm{a}}$, G. Myneni ${ }^{\mathrm{a}}$, A. Schmidt $^{\mathrm{b}, 2}$, J. Iversen $^{\mathrm{b}}$, A. Matheisen $^{\mathrm{b}}$, \\ W. Singer ${ }^{b}$ \\ ${ }^{a}$ Thomas Jefferson National Accelerator Facility, 12000 Jefferson Avenue, Newport News, VA \\ 23606, USA \\ ${ }^{b}$ Deutsches Elektronen-Synchrotron, Notkestraße 85, 22607 Hamburg, Germany
}

\begin{abstract}
Radio-frequency cavities made of bulk niobium are one of the components used in modern particle accelerators. The mechanical stability is an important aspect of cavity design, which typically relies on finite-element analysis simulations using material properties from tensile tests on sample. This contribution presents the results of strain and resonant frequency measurements as a function of a uniform pressure up to $620 \mathrm{kPa}$, applied to single-cell niobium cavities with different crystallographic structure, purity and treatments. In addition, burst tests of high-purity multi-cell cavities with different crystallographic structure have been conducted up to the tensile strength of the material. Finite-element analysis of the single-cell cavity geometry is in good agreement with the observed behavior in the elastic regime assuming a Young's modulus value of $88.5 \mathrm{GPa}$ and a Poisson's ratio of 0.4 , regardless of crystallographic structure, purity or treatment. However, the measured yield strength and tensile strength depend on crystallographic structure, material purity and treatment. In particular, the results from this study show that the mechanical properties of niobium cavities made from ingot material with large crystals are comparable to those of cavities made of fine-grain niobium.
\end{abstract}

\section{Keywords}

Strain measurement, mechanical properties, niobium

\section{Introduction}

Modern particle accelerators used for both fundamental and applied research rely on superconducting radio-frequency (SRF) niobium cavities to efficiently accelerate charged particle beams. Cylindrically symmetric, multi-cell cavities with an "elliptical" shape are typically used for acceleration of particles with velocity in the range $0.4-1$, relative to the speed of light [1]. The material most commonly used for the fabrication of such structures is bulk niobium, because of its superconducting properties below $9.2 \mathrm{~K}$. The material thickness is in the range $2.8-4 \mathrm{~mm}$, depending on the cavity size. The material purity, defined by the residual

\footnotetext{
${ }^{1}$ gciovati@jlab.org

${ }^{2}$ Present address: European XFEL GmbH, Albert Einstein Ring 19, 22761 Hamburg, Germany.
} 
resistivity ratio (RRR), is $R R R>250$ and the grain size is $\sim 50 \mu \mathrm{m}(\mathrm{ASTM} \geq 5)$ [2]. The cavity fabrication method most commonly used consists of deep-drawing niobium discs into half-cell cups which are then joined by electron-beam welding with full-penetration welds. Niobium discs with much larger crystals $\left(>1 \times 1 \mathrm{~cm}^{2}\right)$, directly sliced from an ingot, have also been used successfully over the past decade to fabricate single and multi-cell cavities [3].

After fabrication, niobium cavities are typically subjected to mechanical tuning, chemical or electrochemical polishing and vacuum heat treatments at temperatures of $600{ }^{\circ} \mathrm{C}$ or higher for several hours $[4,5]$.

An important aspect of cavity design is a structural analysis under different load conditions to verify that the maximum stress is well below the yield strength of the material. Typically, the highest load applied to the cavities occurs at the beginning of a cavity cool-down from $300 \mathrm{~K}$ to liquid He temperature inside a cryomodule, when loading due to a mechanical tuner attached to the cavity and pressurized helium gas flowing around the cavity occurs [6].

In recent years, it was also realized that cavities can be considered part of a "pressure vessel", as they are part of the boundary of a liquid helium reservoir, and therefore the structural and material analysis should comply with "pressure vessel code" specifications, which are different in different regions of the world [7-9].

The structural analysis of cavities is typically done using commercial finite-element analysis (FEA) computer software, such as ANSYS or ABAQUS, with user-defined stress versus strain curves for the niobium material. Such stress versus strain curves are derived from "conservative" reviews of literature data from uniaxial tensile tests of flat samples which had been subjected to different treatments. The literature data show a progressive reduction of both yield and tensile strength of fine-grain $\mathrm{Nb}$ after heat-treatment at increasingly higher temperature, above $\sim 600{ }^{\circ} \mathrm{C}$ [10-12]. However, large variations in the values of yield and tensile strength have been reported even for samples subjected to the same treatment, depending on batches of material and/or material supplier [13-16]. The situation is even more complicated when considering ingot $\mathrm{Nb}$ material, for which tensile test samples typically only have 1-2 grains which results in a large variability in tensile test results, depending on the crystal orientation of the samples [12, 17-19]. Furthermore, the $\mathrm{Nb}$ material is subjected to a plastic deformation during the deep-drawing into half-cells and, as a result of the subsequent annealing of the entire $\mathrm{Nb}$ cavity, the behavior of the material under mechanical loading can, in general, be different than for the case of flat tensile test samples which have no initial plastic deformation [20].

In order to address these issues and to provide a more accurate assessment of the mechanical properties of $\mathrm{Nb}$ cavities, we pursued measurements of the local strain and resonant frequency of single-cell cavities of the same shape subjected to an increasing uniform external pressure at room temperature, which mimic the external pressurization of cavities with $\mathrm{He}$ gas at the beginning of the cool-down. The resonant frequency of the cavity provides a sensitive measurement of the overall deformation under external pressure. Although the approach we described has been implemented few times throughout the years [21, 22], the results we present 
are, to the authors' knowledge, the first systematic study of this kind. The experimental data have been used to guide the FEA of the cavity.

As mentioned above, in recent years it became necessary for $\mathrm{Nb}$ cavities welded to He-vessels to be certified with respect to pressure vessel code, before installation and operation in a particle accelerator. As part of the certification process, a FEA of the cavity-He-vessel structure should demonstrate that safety design criteria have been met. Furthermore, the fabricated structure may require destructive burst tests for verification. An example of this process is the certification of 1.3 GHz 9-cell cavities being built for the European X-FEL at DESY [23, 24]. In this article we summarize the results from FEA of the cavity-He-vessel structure and from burst tests of two 9cell cavities made of high-purity fine-grain and ingot $\mathrm{Nb}$.

\section{Materials and methods}

\subsection{Nb material}

Four single-cell cavities built from different $\mathrm{Nb}$ material have been used for the study presented in this article. One cavity, labelled "FG" was made from fine-grain (ASTM $\geq 5), \mathrm{RRR}>250$ discs with tantalum content below 500 wt.ppm, supplied by ATI Wah Chang, USA. A second cavity, labelled "F1F2", was made from discs sliced from an ingot (grain size greater than $\sim 1 \times 1 \mathrm{~cm}^{2}$ ) with RRR 100, Ta content 1300 wt.ppm, supplied by CBMM, Brazil. A third cavity, labelled "G1G2", was made from discs sliced from another ingot (grain size greater than $\sim 1 \times 1 \mathrm{~cm}^{2}$ ) with RRR 100, Ta content $~ 1300$ wt.ppm, supplied by CBMM, Brazil. The fourth cavity, labelled "H1H2" was made from discs sliced from an ingot with the same RRR as the other two but lower Ta content ( 700 wt.ppm), also supplied by CBMM, Brazil.

Two nine-cell cavities have been used for testing related to compliance with pressure vessel codes at DESY. One cavity, labelled "Z102" was made of fine-grain Nb discs from Tokyo Denkai, Japan, with RRR>300, Ta $<500$ wt. ppm, while the other cavity, labelled "AC153" was made from ingot $\mathrm{Nb}$ discs with the same purity specifications as the fine-grain ones, supplied by W.C. Heraeus, Germany.

\subsection{Cavity fabrication and treatments}

The $\mathrm{Nb}$ discs of $3.175 \mathrm{~mm}$ thickness have been deep-drawn into half-cells using Aluminum 6061 dies lubricated with $5 \mathrm{~W} 30$ motor oil and using 150 ton pressure. The inner diameter at the iris is $70 \mathrm{~mm}$ whereas the inner diameter at the equator is $118 \mathrm{~mm}$. The half-cell length is $5 \mathrm{~cm}$. Each half-cell was welded by EBW to a $38 \mathrm{~cm}$ long $\mathrm{Nb}$ tube with Ti-45Nb flanges at its end. EBW was done from both the inside and the outside. The single-cell cavity is then completed with a final full-penetration EBW from the outside to join the two half-cells. The thickness in the weld regions was reduced to $1.59 \mathrm{~mm}$ on a milling machine prior to welding. The cell's shape is the same as that of the original cavities used in the CEBAF accelerator at Jefferson Lab [25]. The resonant frequency of the cavity's accelerating mode is $1.5 \mathrm{GHz}$. 
The destructive test required for pressure vessel code certification and related to the ultimate tensile strength of the material was done on two nine-cell cavities of the same shape as that of cavities being fabricated for the X-FEL accelerator at DESY [26]. The fabrication method was the same as that outlined for the single-cell cavities although the material had an initial thickness of $2.8 \mathrm{~mm}$. The resonant frequency of the nine-cell cavities is $1.3 \mathrm{GHz}$. Fig. 1 shows a drawing of the $1.5 \mathrm{GHz}$ single-cell cavity and the $1.3 \mathrm{GHz}$ nine-cell cavity.

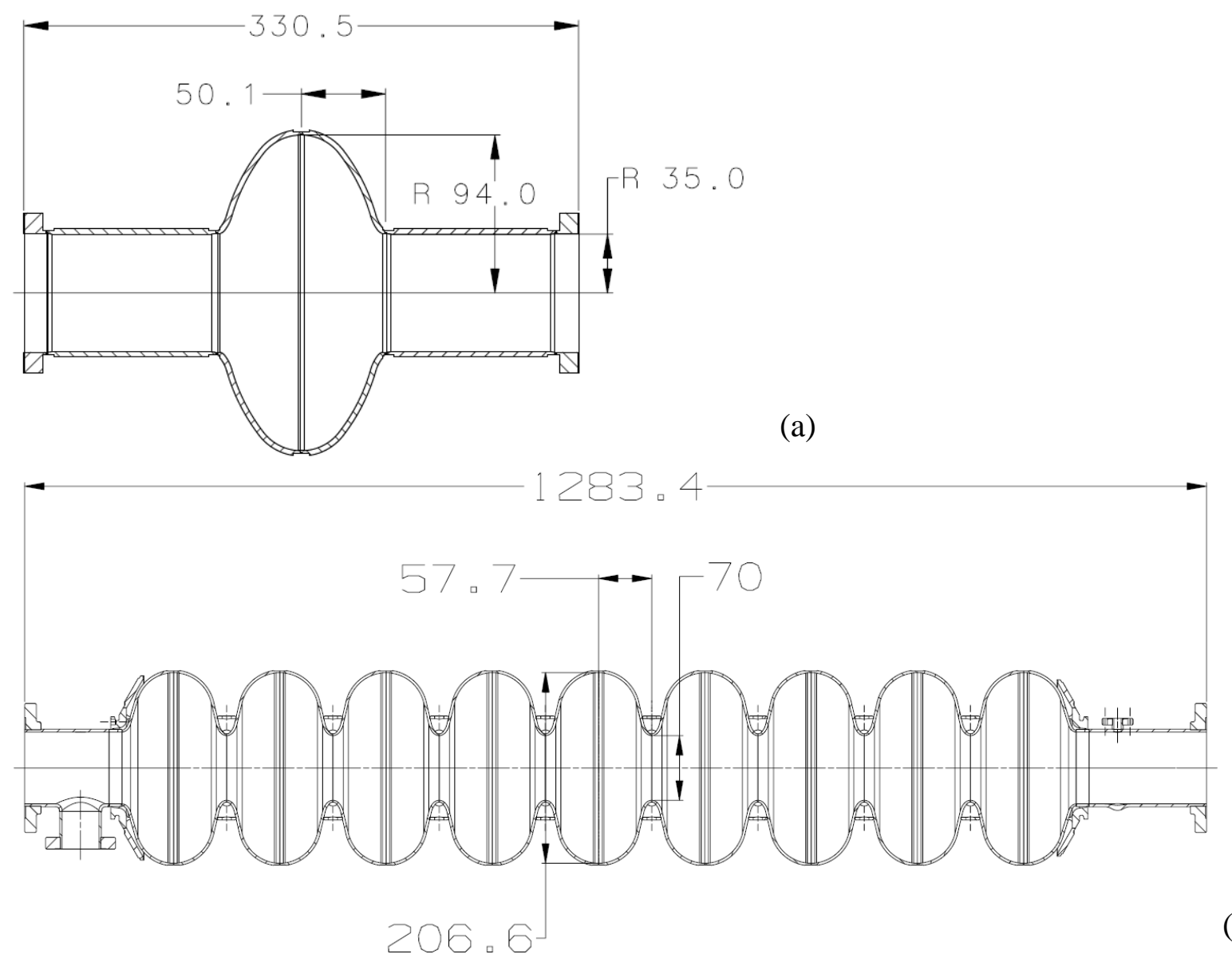

(b)

Fig. 1. (a) Cross section of the $1.5 \mathrm{GHz}$ original Cornell CEBAF shape single-cell cavity and (b) cross-section of the $1.3 \mathrm{GHz}$ TESLA/X-FEL shape nine-cell cavity. Stiffening rings welded between irises of adjacent cells can be seen in (b). Dimensions are in $\mathrm{mm}$.

The treatments for each cavity, prior to the pressure test, are summarized in the following paragraphs and shown schematically in Fig. 2.

After fabrication, cavity "FG" was etched by buffered chemical polishing (BCP) with $\mathrm{HF}: \mathrm{HNO}_{3}: \mathrm{H}_{3} \mathrm{PO}_{4}=1: 1: 1$ removing $\sim 140 \mu \mathrm{m}$ from the inner surface, followed by $\sim 30 \mu \mathrm{m}$ additional removal by vertical electropolishing (EP). The cavity was then heat treated at 600 ${ }^{\circ} \mathrm{C} / 10 \mathrm{~h}$ in a vacuum furnace, followed by $\sim 130 \mu \mathrm{m}$ removal by centrifugal barrel polishing (CBP), $600{ }^{\circ} \mathrm{C} / 10 \mathrm{~h}$ heat treatment and $\sim 7 \mu \mathrm{m}$ material removal by horizontal EP. After the 
pressure test, the cavity was heat treated in a vacuum furnace at $800{ }^{\circ} \mathrm{C}$ for $2 \mathrm{~h}$ and the pressure test was repeated.

Cavity "F3F4" was pressure tested after fabrication, without any treatment. After the test, $\sim 100 \mu \mathrm{m}$ of material was removed from the inner surface by CBP, followed by $\sim 50 \mu \mathrm{m}$ material removal by BCP. The cavity was then heat treated in a vacuum furnace at $800{ }^{\circ} \mathrm{C}$ for $2 \mathrm{~h}$ and the pressure test was repeated.

After fabrication, $\sim 70 \mu \mathrm{m}$ of material were removed from the inner surface of cavity "G1G2" by $\mathrm{CBP}$, followed by an additional $\sim 65 \mu \mathrm{m}$ removal by BCP. The cavity underwent a series of heat treatments in a vacuum furnace at $800{ }^{\circ} \mathrm{C} / 3 \mathrm{~h}, 800{ }^{\circ} \mathrm{C} / 6 \mathrm{~h}, 1000{ }^{\circ} \mathrm{C} / 6 \mathrm{~h}, 1200{ }^{\circ} \mathrm{C} / 6 \mathrm{~h}, 1400{ }^{\circ} \mathrm{C} / 3$ $\mathrm{h}, 1400{ }^{\circ} \mathrm{C} / 3 \mathrm{~h}$ for a second time, $1400{ }^{\circ} \mathrm{C} / 3 \mathrm{~h}$ for a third time, $1250{ }^{\circ} \mathrm{C} / 3 \mathrm{~h}, 1300{ }^{\circ} \mathrm{C} / 3 \mathrm{~h}$. Etching by $\mathrm{BCP}$ removing 10-30 $\mu \mathrm{m}$ of material from the inner surface was done after each heat treatment. The final treatments prior to the pressure test was a heat treatment at $800{ }^{\circ} \mathrm{C} / 3 \mathrm{~h}$ with a nitrogen pressure $\sim 2.7 \mathrm{~Pa}$ held inside the vacuum furnace for $2 \mathrm{~min}$ before furnace cool-down followed by $\sim 7 \mu \mathrm{m}$ removal by horizontal EP.

After fabrication, cavity "H1H2" was etched by BCP removing $~ 70 \mu \mathrm{m}$ of material from the inner surface followed by heat treatments at $600{ }^{\circ} \mathrm{C} / 10 \mathrm{~h}$ and $1400{ }^{\circ} \mathrm{C} / 3 \mathrm{~h}$. About $30 \mu \mathrm{m}$ of material were removed by CBP, followed by $\sim 50 \mu \mathrm{m} \mathrm{BCP,} 20 \mu \mathrm{m}$ horizontal EP. The final treatment prior to pressure test was a heat treatment at $1400{ }^{\circ} \mathrm{C} / 30 \mathrm{~min}$.

The typical temperature ramp-up rate for all heat treatments was $\sim 5^{\circ} \mathrm{C} / \mathrm{min}$ and the total pressure at temperature was below $\sim 10^{-3} \mathrm{~Pa}$.

The thickness, $d$, of each single-cell cavity was measured prior to the pressure test in six places along the contour with an ultrasonic probe. The uncertainty in the thickness measurement at each location is $5-10 \mu \mathrm{m}$.

Cavity "Z102" was subjected to the following treatments after fabrication: $144 \mu \mathrm{m}$ inner material removal by $\mathrm{EP}$ and $\sim 20 \mu \mathrm{m}$ outer material removal by $\mathrm{BCP}$, annealing at $800{ }^{\circ} \mathrm{C} / 2 \mathrm{~h}, 57 \mu \mathrm{m}$ removal from inner surface by EP. Cavity "AC153" was subjected to the following treatments after fabrication [27]: $100 \mu \mathrm{m}$ inner material removal and $20 \mu \mathrm{m}$ outer material removal by BCP, annealing at $800{ }^{\circ} \mathrm{C} / 2 \mathrm{~h}, 20 \mu \mathrm{m}$ removal from inner surface by $\mathrm{BCP}$, baking at $\sim 130{ }^{\circ} \mathrm{C} / 48 \mathrm{~h}$, $\sim 60 \mu \mathrm{m}$ inner material removal by EP, second annealing at $800^{\circ} \mathrm{C} / 2 \mathrm{~h}$, final EP removing $\sim 50 \mu \mathrm{m}$, baking at $120^{\circ} \mathrm{C} / 48 \mathrm{~h}$.

The cavities' label, resonant frequency, material type and supplier, purity, Ta content and average thickness are listed in Table 1. The thickness of the 9-cell cavities is estimated based on material removal. The RRR was calculated as the ratio of the resistivity at $295 \mathrm{~K}$ divided by the resistivity at $10 \mathrm{~K}$ measured with a standard four-probe method on small samples cut from the ingots or sheets and processed with similar treatments as the cavities. 
Table 1. Cavities' label, resonant frequency, material type and supplier, RRR and average thickness.

\begin{tabular}{|c|c|c|c|c|c|}
\hline $\begin{array}{l}\text { Cavity } \\
\text { Label }\end{array}$ & $\begin{array}{l}\text { Frequency } \\
(\mathrm{GHz})\end{array}$ & $\begin{array}{l}\text { Material type and } \\
\text { supplier }\end{array}$ & RRR & $\begin{array}{l}\text { Ta content } \\
\text { (wt. ppm) }\end{array}$ & $\begin{array}{l}\text { Thickness, } d \\
(\mathrm{~mm})\end{array}$ \\
\hline FG & 1.46 & $\begin{array}{l}\text { Fine-grain, ATI } \\
\text { Wah Chang }\end{array}$ & $>250$ & $<500$ & $2.79 \pm 0.11$ \\
\hline Z102 & 1.30 & $\begin{array}{l}\text { Fine-grain, Tokyo } \\
\text { Denkai }\end{array}$ & $>300$ & $<500$ & $\sim 2.58$ \\
\hline F3F4 & 1.47 & Ingot F, CBMM & $110 \pm 20$ & 1330 & $3.05 \pm 0.07^{\mathrm{a}}$ \\
\hline G1G2 & 1.47 & Ingot G, CBMM & $105 \pm 10$ & 1375 & $2.98 \pm 0.10$ \\
\hline $\mathrm{H} 1 \mathrm{H} 2$ & 1.46 & Ingot $\mathrm{H}, \mathrm{CBMM}$ & $105 \pm 10$ & 704 & $2.89 \pm 0.03$ \\
\hline AC153 & 1.30 & Ingot, Heraeus & $>300$ & $<500$ & $\sim 2.57$ \\
\hline
\end{tabular}

${ }^{\mathrm{a}}$ The thickness after CBP and BCP decreased to (2.90 \pm 0.08$) \mathrm{mm}$.

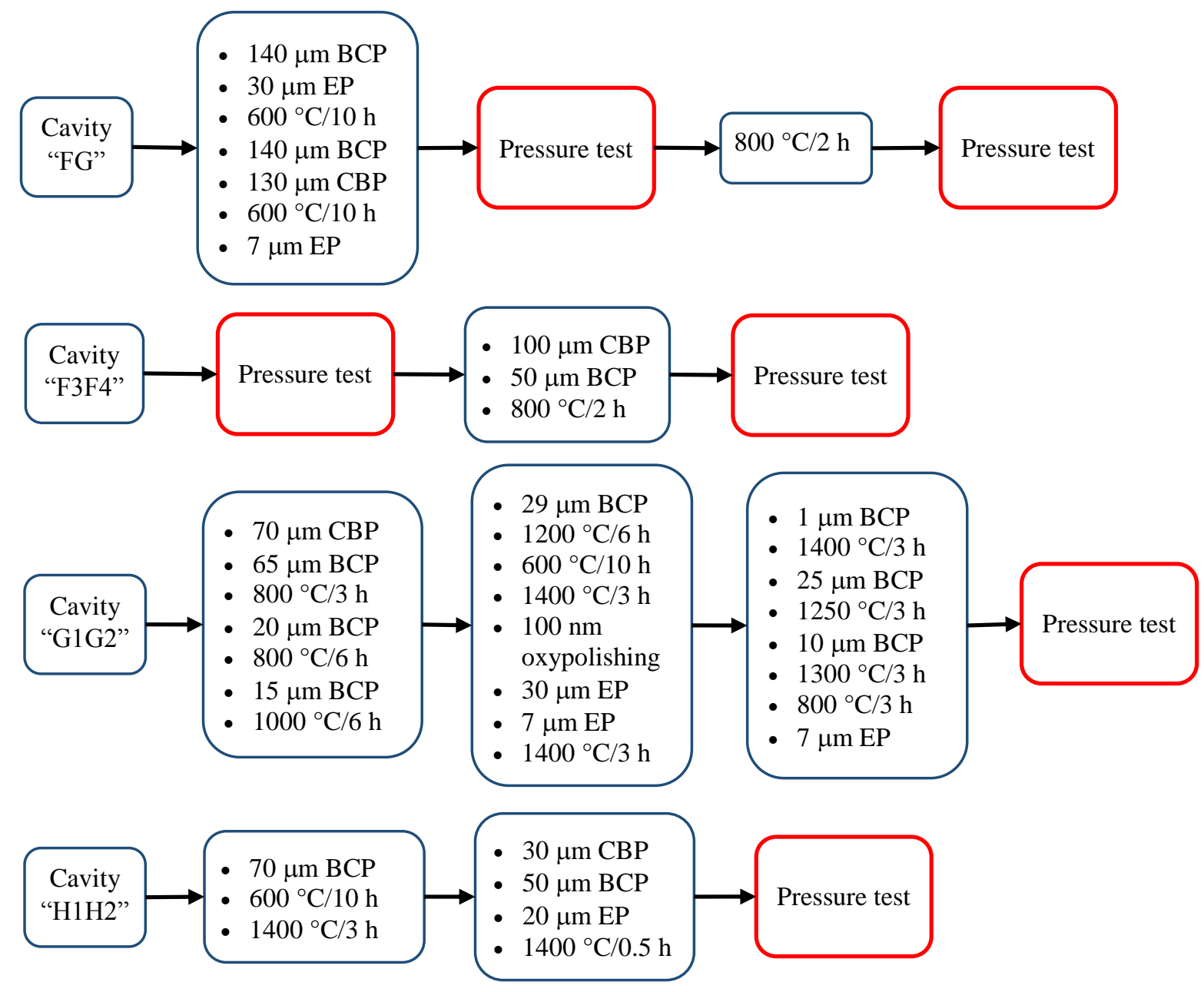

Fig. 2. Schematic of the treatments done to the single-cell cavities prior to pressure tests. 


\subsection{Instrumentation}

Six calibrated $120 \Omega$ strain gages were glued to each single-cell cavity prior to each pressure test to measure the local strain. Four gages were attached within $9 \mathrm{~mm}$ from the center of the iris weld. These gages are miniature $(0.76 \mathrm{~mm}$ gage length) tee-rosettes (EA-06-030-TU-120, MicroMeasurements, USA, gage factor $=2.08$ ) which allow measuring strain along the azimuthal (gages 1 and 3) and longitudinal (gages 2 and 4) directions. Two gages (CEA-06-125-UW-120, Micro-Measurements, USA, gage factor $=2.11$, gage length $=3.18 \mathrm{~mm}$ ) were attached in the equator area, one (gage 5) at $32 \mathrm{~mm}$ from the center of the equator weld, the other (gage 6) at 10$17 \mathrm{~mm}$ from the center of the equator weld. The azimuthal spacing among each sensor is $\sim 90^{\circ}$. The surface preparation and bonding procedures followed those recommended by the strain gage manufacturer $[28,29]$. Three Teflon insulated copper wires are soldered to each strain gage. Environmental protection of each gage consists of one layer of M-Coat A (Micro-Measurements, USA) and RTV-3140 silicone coating (Dow-Corning, USA) applied on top.

The cavity ends were sealed with stainless steel blanks clamped to the cavity flanges. Indium wire $1.5 \mathrm{~mm}$ in diameter was used as gasket. The inner volume of the cavity is at $1 \mathrm{~atm}$. An RF feedthrough with a $10 \mathrm{~cm}$ long copper antenna is bolted to a $34 \mathrm{~mm}$ diameter Conflat flange which is welded to one of the blanks.

The single-cell cavity is suspended on an Aluminum frame, with four points of contact with the cell, inside a 227 liter (60 gal) stainless steel pressure tank rated up to $760 \mathrm{kPa}$. One end of an RF cable is connected to the RF feedthrough to measure the cavity resonance frequency. The other end of the cable is outside the tank, through a $70 \mathrm{~mm}$ Conflat flange epoxied to the cable. Microcrystalline wax was used to isolate the RF connection from water. The wires from the strain gages were soldered to the wires of a feedthrough bolted to the pressure tank. The soldered sections were isolated from water with heat-shrink tubing and liquid tape (Plasti Dip, USA).

The cavity resonant frequency is determined as the minimum of the reflection coefficient in the resonance curve measured with a network analyzer (Model E5071C, Agilent, USA). The pressure and temperature inside the tank were measured with a $0.101-1.136 \mathrm{MPa}(0-150 \mathrm{psig})$ dial pressure gage and a digital thermometer $\left(0.1^{\circ} \mathrm{C}\right.$ resolution $)$ attached to the tank. A hydrostatic test pump (Model 29200, Wheeler-Rex, USA) is used to increase the water pressure inside the tank.

Wires from the strain gages were connected to a strain gages indicator (Model P3, MicroMeasurements, USA) in quarter-bridge configuration. Fig. 3 shows the strain gages attached to the cavity. Fig. 4 shows the cavity inside the pressure tank and the measurement setup. 


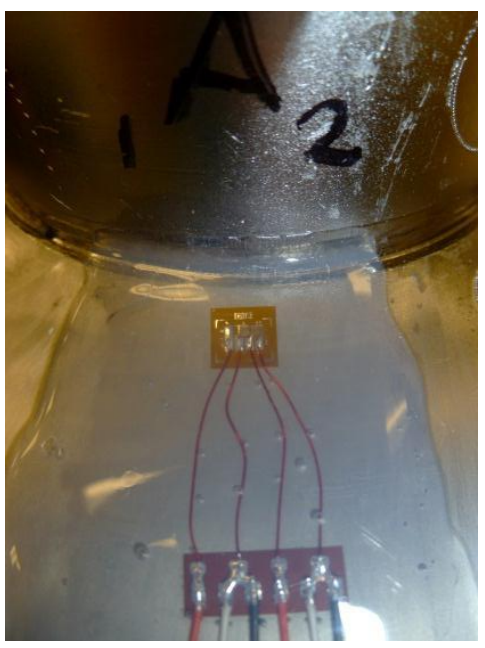

(a)

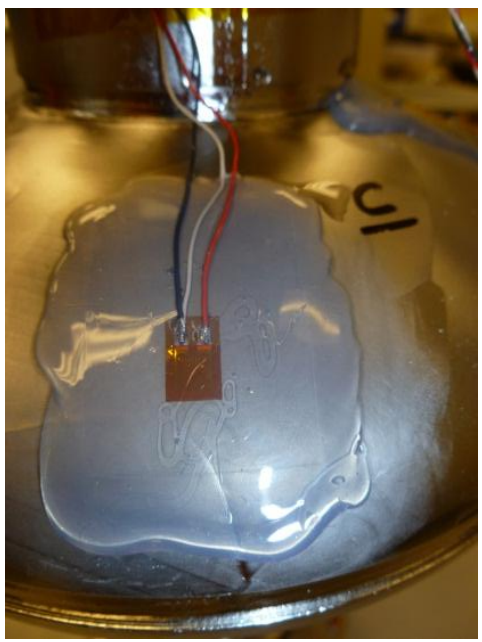

(b)

Fig. 3. Pictures of a tee-rosette strain gage bonded near the iris (a) and a single strain gage bonded near the equator (b) of one of the single-cell cavities prepared for the pressure test.
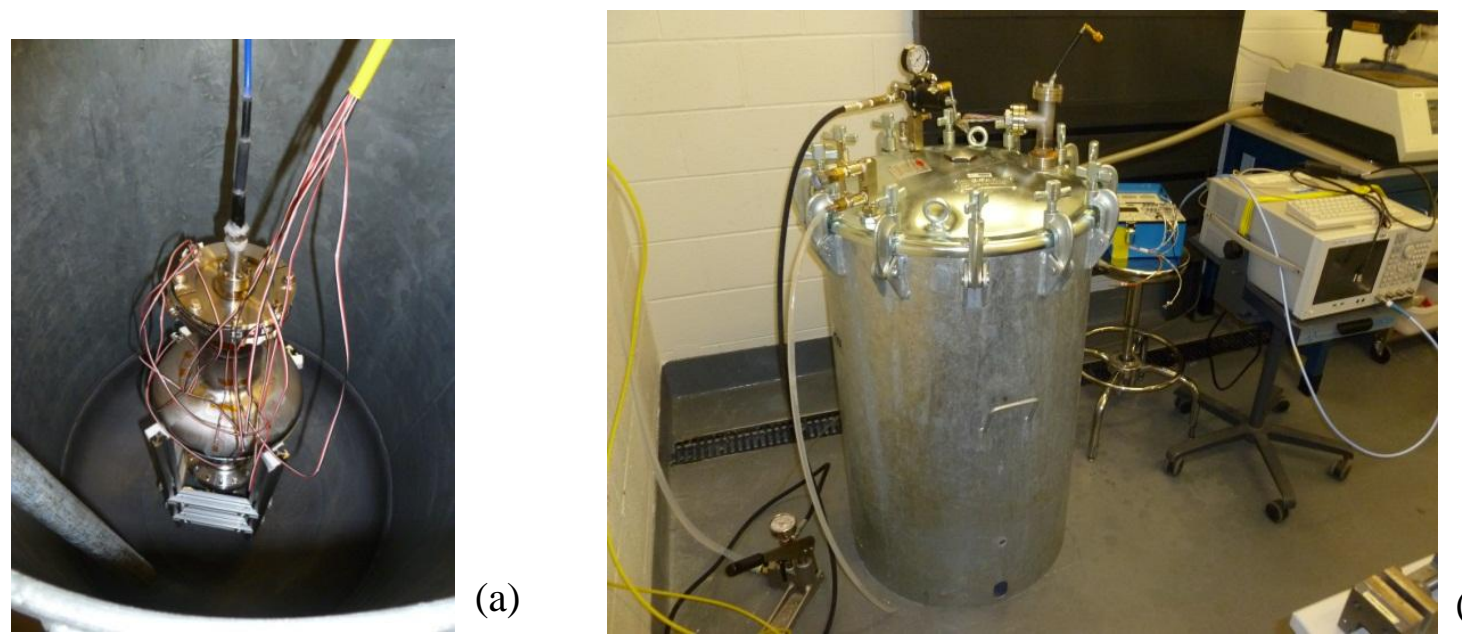

(b)

Fig. 4. Picture of the cavity inside the pressure tank (a) and of the experimental setup for the pressure test of single-cell cavities at Jefferson Lab (b).

The nine-cell cavities were welded into a titanium Helium vessel with a bellows at one end. The cavity with He-vessel is held horizontally in a support frame. The resonant frequency is measured at the maximum of the transmission coefficient through two antennae at both ends of the cavity, using a network analyzer. Several analog dial indicators are used to measure the displacement at the cavity ends, during pressurization. The inside volume of the cavity is at standard temperature and pressure whereas the volume between the cavity and He vessel is filled with water. A hydrostatic test pump with a calibrated gage is used to increase the water pressure inside the He vessel. An image of the experimental setup is shown in Fig. 5. 


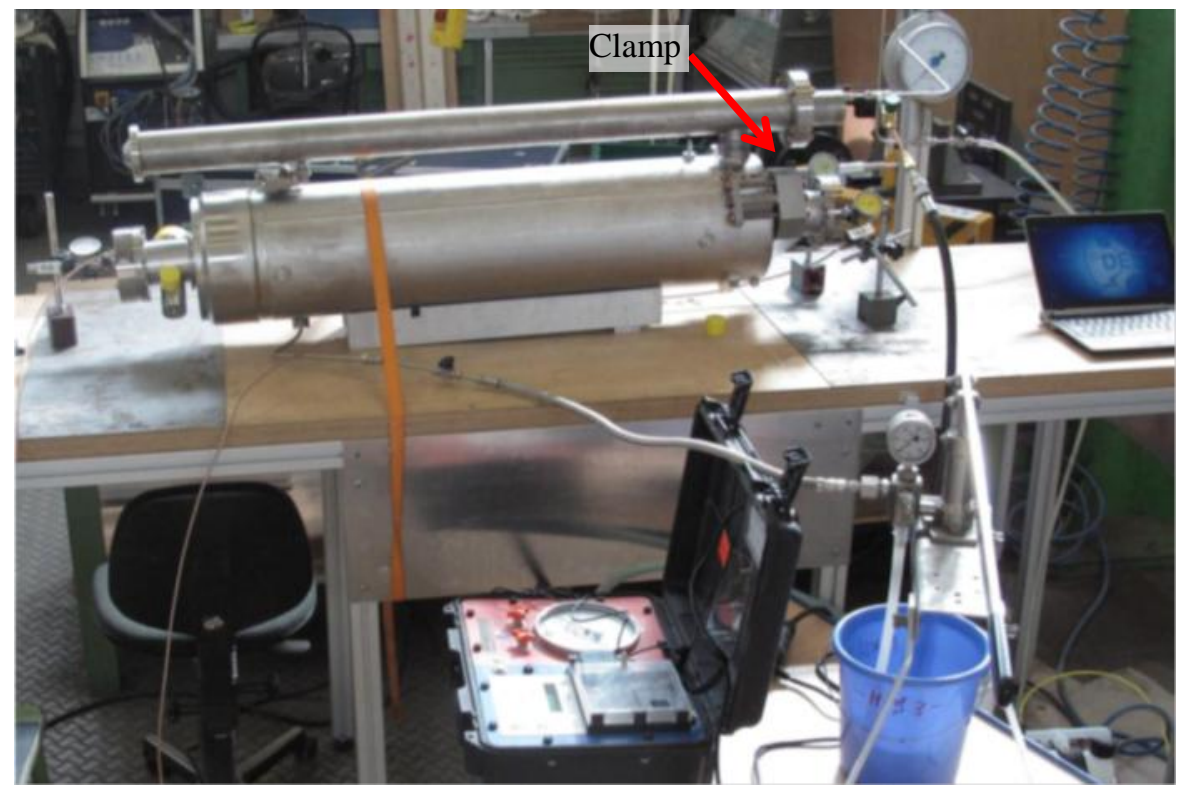

Fig. 5. Picture of the experimental setup used at DESY for the pressure test of the 9-cell cavities welded into the cylindrical Ti Helium-vessel. A clamp is used to hold the bellows between the cavity and the He-vessel.

\subsection{Measurement procedure}

The pressure test of the single-cell cavities was done as follows: the pressure tank is filled with ultra-pure water at atmospheric pressure. The bridge for each of the four channels of the P3 instrument is balanced and the resonant frequency is measured. Two channels are shared between strain gages 1 and 2 and gages 3 and 4 and manual switching of the wires into the channels' terminals was done for each measurement.

The water pressure is increased to a relative pressure of $69 \mathrm{kPa}(10 \mathrm{psig})$ and held while measuring strain, frequency and temperature. The pressure is then relieved through a relief valve on the tank and strain, frequency and temperature are measured at zero relative pressure. The same measurement procedure is repeated after increasing the water pressure by $34.5 \mathrm{kPa}$ increments, up to a relative pressure of $620.5 \mathrm{kPa}$. A second measurement is taken where the water pressure is monotonously increased at $34.5-69 \mathrm{kPa}$ steps, up to a relative pressure of $620.5 \mathrm{kPa}$, without relieving the pressure after each step.

The pressure test of the 9-cell cavities was done by gradually increasing the water pressure and measuring frequency and displacement after each step. For the test of the fine-grain cavity, the pressure was released after each $100-200 \mathrm{kPa}$ incremental step. For the test of the large-grain cavity, the pressure was first released after loading at 1.6 MPa. The pressure was raised until the cavity ruptured and water entered into the cavity. 


\subsection{Finite element analysis}

The outer contour of one of the single-cell cavities was measured with a coordinate measuring machine at 4 azimuthal locations, $90^{\circ}$ apart. Three-dimensional models with thickness equal to the average wall thickness of each cavity was generated from the data taken with a coordinate measuring machine and imported into ANSYS Workbench version 14.5 [30]. An elastic static structural model was considered and the niobium material properties were defined as isotropic. The Young's modulus was $88.5 \mathrm{GPa}$ and different values of Poisson's ratio, $v$, between 0.2 and 0.4 were considered for the analysis. Roughly 46,400 triangular-shaped elements were utilized to mesh the cell. Fig. 6 shows images of the meshed cavity and of the von-Mises stresses when applying a $448 \mathrm{kPa}$ uniform relative external pressure, calculated for $v=0.4$ and $d=2.8 \mathrm{~mm}$. The peak von-Mises stress is located at the iris region of the cavity. The pressure sensitivity calculation was done as a combined structural and electromagnetic analysis with about 117,400 triangular-shaped mesh elements.

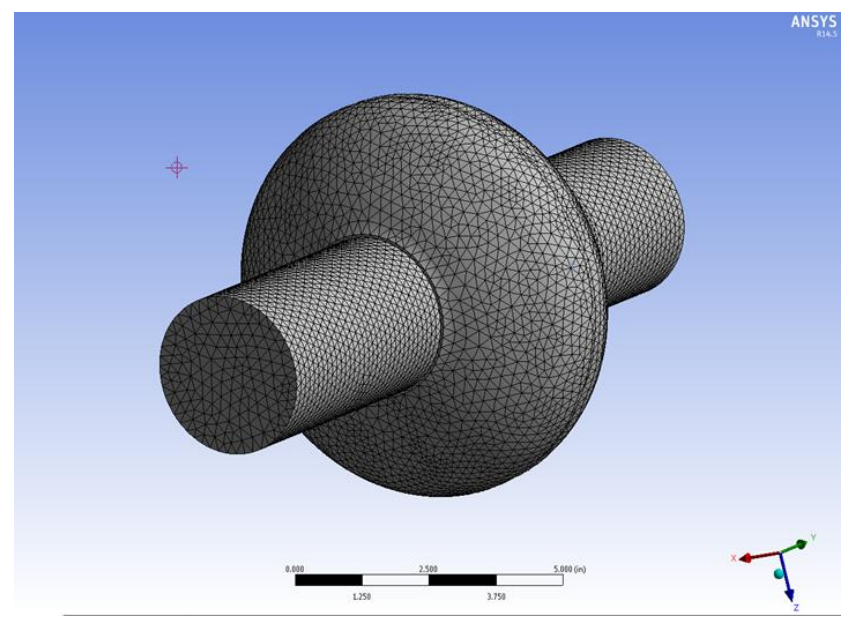

(a)

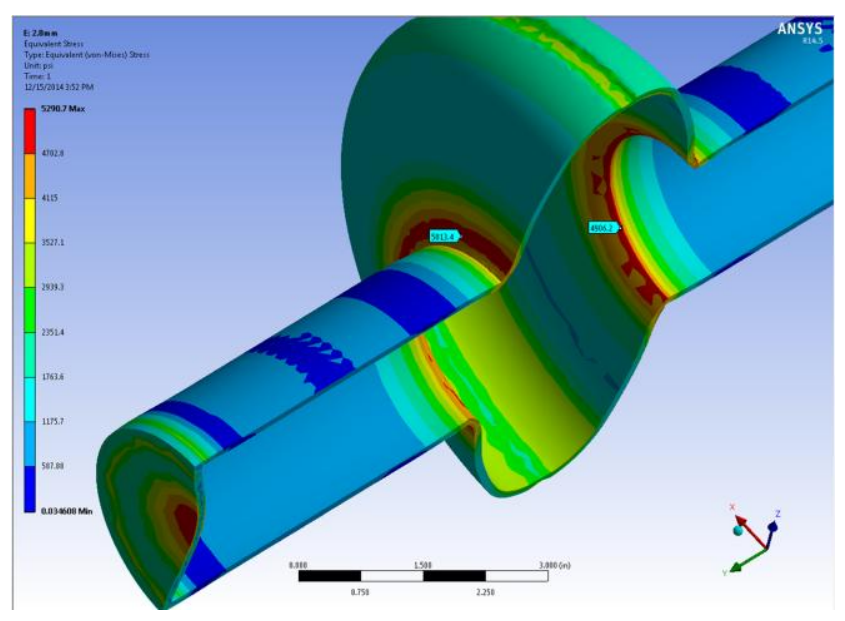

(b)

Fig. 6. Meshing of the 3D model of the single-cell cavity (a) and von-Mises stress calculated for an external relative pressure of $448 \mathrm{kPa}, E=88.5 \mathrm{GPa}, v=0.4$ and $d=2.8 \mathrm{~mm}$ (b). The peak von-Mises stress at the iris region is $\sim 35 \mathrm{MPa}$ whereas it is $\sim 12 \mathrm{MPa}$ in the equator region. 
Initial calculations of the mechanical stability of the 9-cell cavity without He-vessel had been done many years ago and determined the required material thickness and position of the stiffening ring [31]. A finite-element analysis of a rotation-symmetric 2D-model of the 9-cell cavity welded to the He-vessel was done with ANSYS using 8-node mesh elements. A differential pressure of $400 \mathrm{kPa}$ was applied inside the He-vessel. One end of the cavity was fixed. The displacement of the He-vessel relative to the flange on the opposite end of the cavity is limited to $1 \mathrm{~mm}$ in axial direction to account for a mechanical tuner which will be installed to the cavity with He-vessel. The purpose of the finite-element analysis was to validate the mechanical stability of the cavity with He-vessel up to the maximum pressure of $400 \mathrm{kPa}$ which can be established in the E-XFEL accelerator where those cavities will be installed. The finiteelement analysis followed the guidance of the European code EN 13445-3 [32]. The Nb material properties used for the simulation calculation were: $E=106 \mathrm{GPa}, v=0.4$, and a yield strength of 50-100 MPa for high purity $\mathrm{Nb}$. The results from the finite-element analysis indicated that the locations of high stresses were in the weld region of the He-vessel, in the bellows between Hevessel and cavity and at the weld between the stiffening ring and the cavity wall, as shown in Fig. 7 [32]. The results after linearization of the peak von Mises stresses through the materials' thickness and classification according to EN 13445-3 were that stresses were below the maximum allowable values for both $\mathrm{Nb}$ and $\mathrm{Ti}$ [33]. 


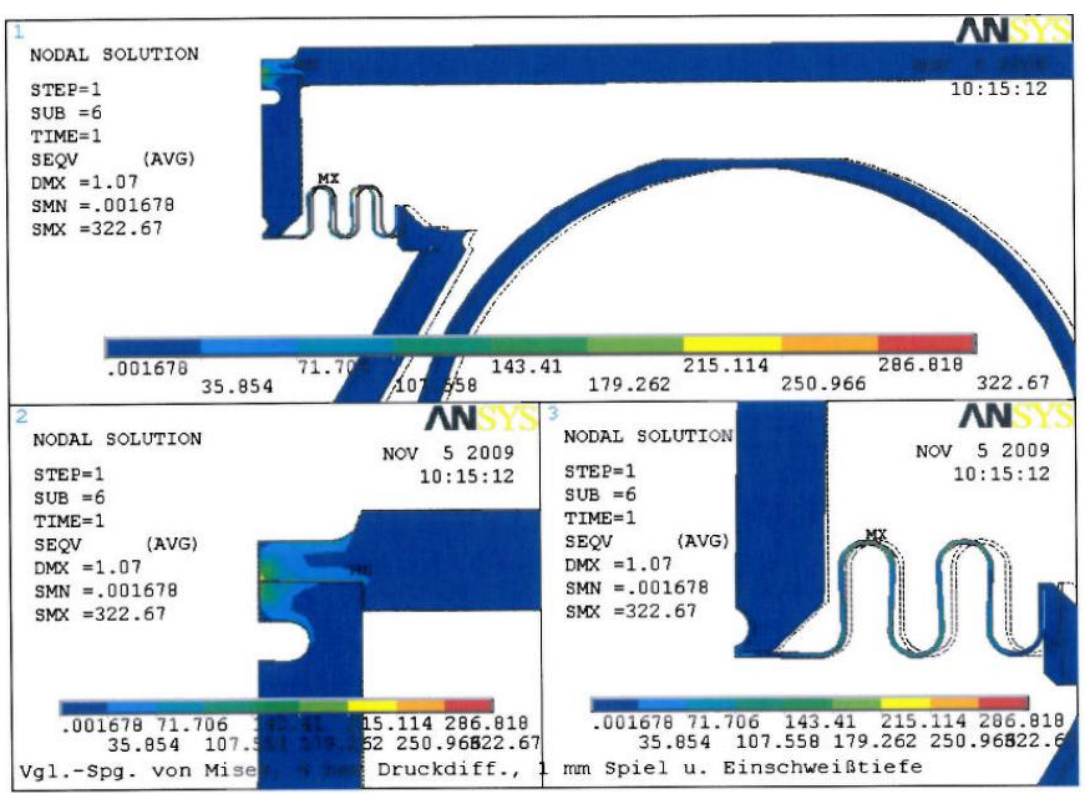

(a)

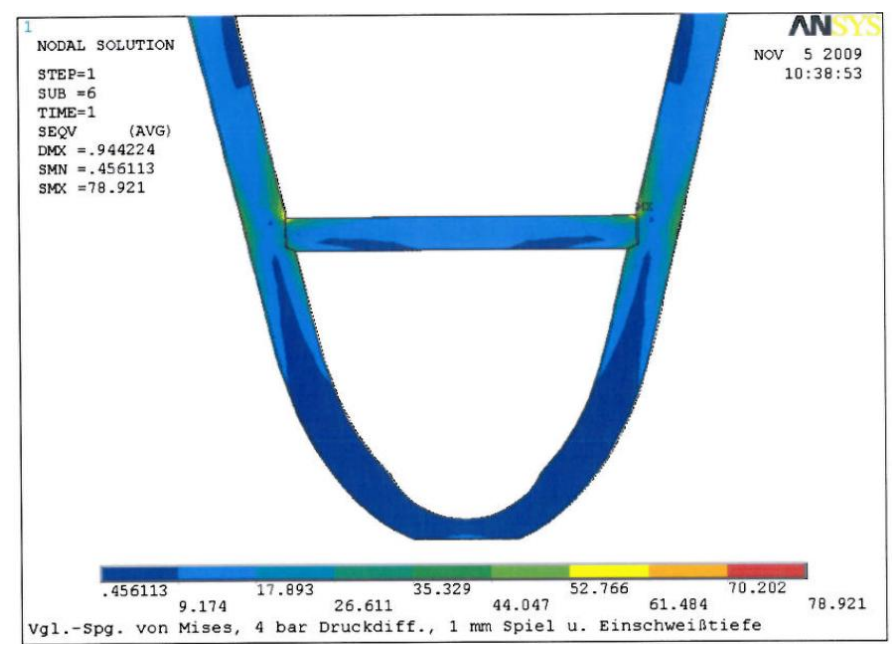

(b)

Fig. 7. Equivalent von-Mises stresses calculated for a uniform pressure of $400 \mathrm{kPa}$ applied between the He vessel and the $\mathrm{Nb}$ cavity showing the highest peak stresses to be at a weld (272 $\mathrm{MPa}$ ) and bellows (323 MPa) of the titanium He-vessel (a) and at the weld between the $\mathrm{Nb}$ stiffening ring and the $\mathrm{Nb}$ cavity wall (79 MPa) (b) [33]. The unit of the stresses in the color maps is MPa. 


\section{Results}

\subsection{Single-cell cavities}

Strain and pressure sensitivity data will be presented for the fine-grain and ingot $\mathrm{Nb}$ cavities described in the previous Section. The uncertainty in the strain measurement has been calculated using the error propagation methods described in [34]. For the tee-rosette gages, errors due to transverse sensitivity, temperature, misalignment and instrument accuracy have been taken into account. For the single gage, the transverse sensitivity error was not considered. The gages misalignment with respect to the principal strain axis was less than $9^{\circ}$ for all cases. The water temperature as a function of pressure was between $18.8^{\circ} \mathrm{C}$ and $19.9{ }^{\circ} \mathrm{C}$ with an uncertainty of $0.4^{\circ} \mathrm{C}$ for all tests. The accuracy of the P3 strain indicator is $3 \mu \mathrm{m} / \mathrm{m}$. As mentioned in Sec. 2.4, two set of measurements have been taken for each test. Since the results are within the experimental errors in all cases, we present only the results from the first set of measurements in which the pressure was relieved after each step, for clarity of the figure plots.

Fig. 8 shows the strain relative to the value at zero relative pressure, $\Delta \varepsilon(P)=\varepsilon(P)-\varepsilon(0)$, as a function of relative pressure, $P$, measured by a tee-rosette at the iris (gages 3 and 4 ) and two single-gages at the equator of ingot $\mathrm{Nb}$ single-cell F3F4 after fabrication, whereas Fig. 9 shows the results after heat treatment at $800{ }^{\circ} \mathrm{C} / 2 \mathrm{~h}$.
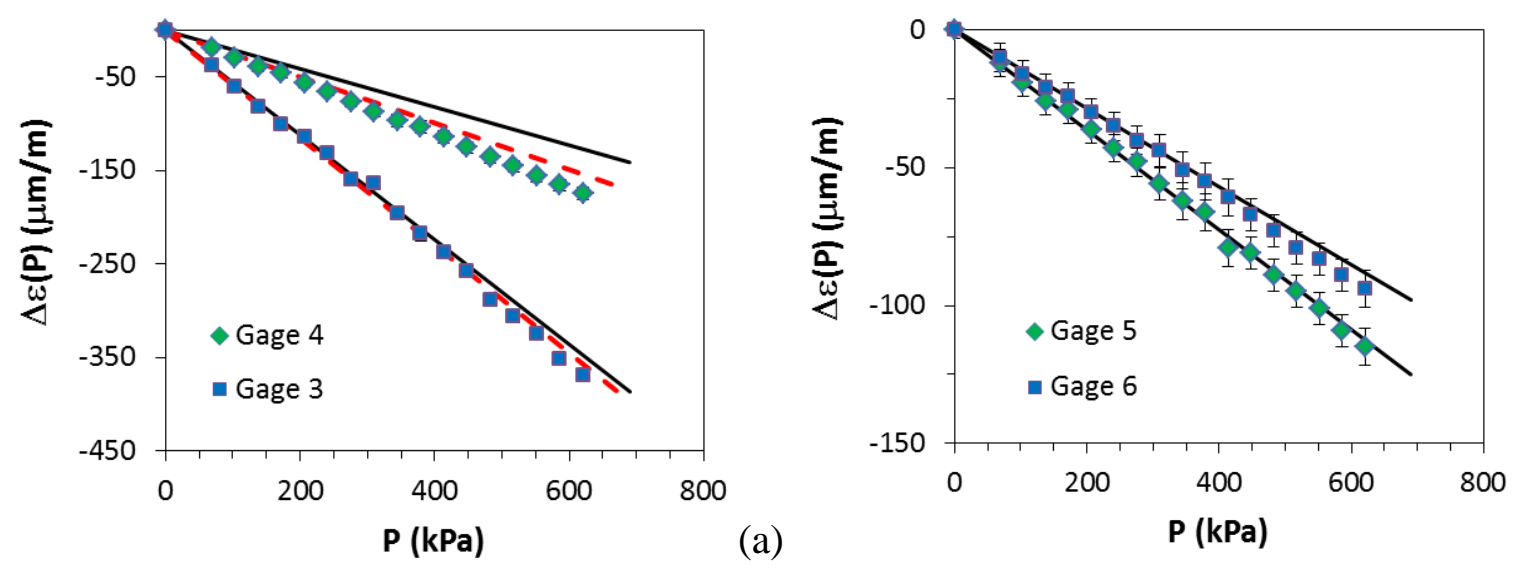

Fig. 8. Strain versus pressure measured at the iris (gage 3 measures strain in the azimuthal direction, gage 4 in the longitudinal one) (a) and equator (gages 5 and 6 measure strain in the longitudinal direction) (b) regions of ingot $\mathrm{Nb}$ single-cell cavity F3F4 after fabrication. Solid and dashed lines are results from FEA with $E=88.5 \mathrm{GPa}, v=0.4$ and $v=0.35$, respectively. The error bars in (a) are of the size of the symbols. 

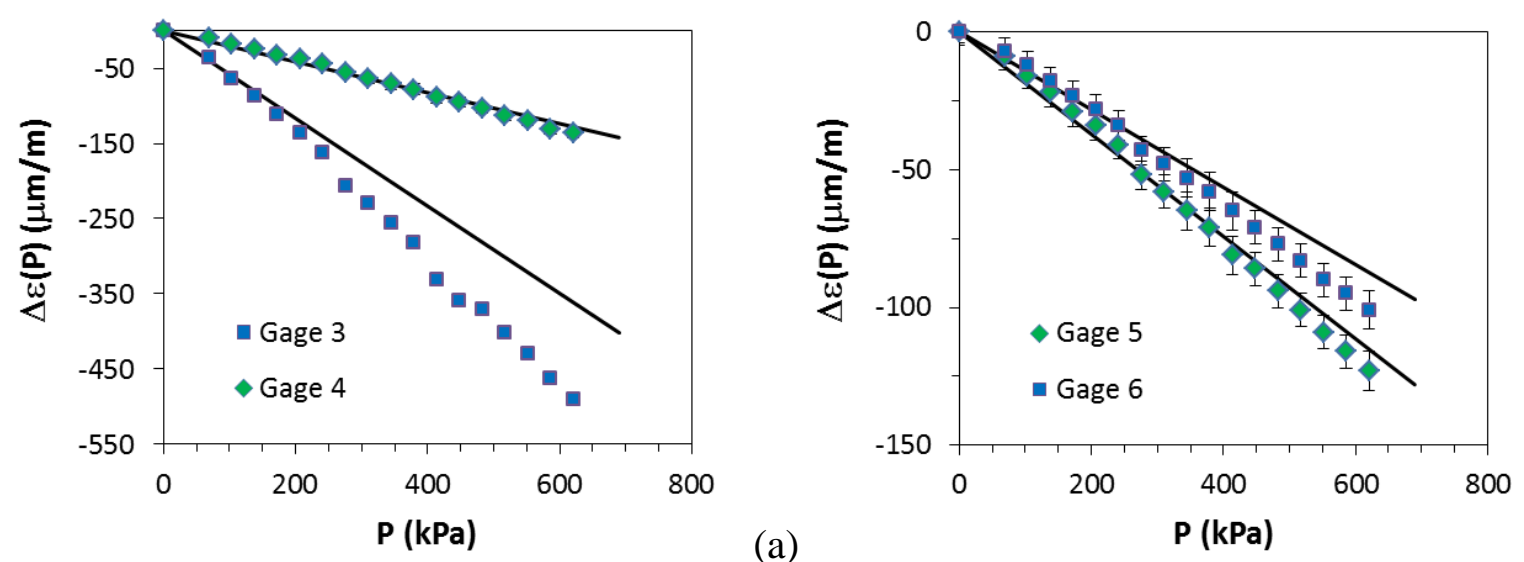

(b)

Fig. 9. Strain versus pressure measured at the iris (gage 3 measures strain in the azimuthal direction, gage 4 in the longitudinal one) (a) and equator (gages 5 and 6 measure strain in the longitudinal direction) (b) regions of ingot $\mathrm{Nb}$ single-cell cavity $\mathrm{F} 3 \mathrm{~F} 4$ after $800{ }^{\circ} \mathrm{C} / 2 \mathrm{~h}$ heat treatment. Solid lines are results from FEA with $E=88.5 \mathrm{GPa}, v=0.4$. The error bars in (a) are of the size of the symbols.

Fig. 10 shows the strain relative to the value at zero relative pressure, $\Delta \varepsilon(P)$, as a function of relative pressure, $P$, measured by a tee-rosette at the iris (gages 3 and 4 ) and two single-gages at the equator of fine-grain $\mathrm{Nb}$ single-cell $\mathrm{FG}$ after a highest heat treatment temperature of $600{ }^{\circ} \mathrm{C} / 10 \mathrm{~h}$, whereas Fig. 11 shows the results after heat treatment at $800^{\circ} \mathrm{C} / 2 \mathrm{~h}$. Besides deviation from linear dependence of $\Delta \varepsilon(P)$, deviations from a constant value of both strain and resonant frequency at zero relative pressure, $\varepsilon(0)$ and $f(0)$, respectively, are an accurate indication of local and global plastic deformation (yielding) of the cavity. Figs. 12 and 13 show $\varepsilon(0)$ and $f(0)$ measured after relieving the applied relative pressure $P$ back to zero for the cavity FG after $600{ }^{\circ} \mathrm{C} / 10 \mathrm{~h}$ and $800{ }^{\circ} \mathrm{C} / 2 \mathrm{~h}$ heat treatments, respectively. Fig. 12 shows a modest but monotonous decrease of the resonant frequency and some residual strain at the iris location. No residual strain was measured for gages at the equator locations (gages 5 and 6) and smaller residual strain was measured at iris location of gages 1 and 2, compared to that at the location of gages 3 and $4\left(180^{\circ}\right.$ apart from the location of gages 1 and 2). The data shown in Fig. 12 are indicative of "micro-yielding" in the material [35]. Recent studies on high-purity fine-grain $\mathrm{Nb}$ showed large batch-to-batch variability in yield strength which was related to the microcrystalline structure of the niobium sheets. In particular, significant micro-structure heterogeneity was found already in the "as-received" samples. Heat treatments above $\sim 700{ }^{\circ} \mathrm{C}$ initiated nonuniform grain growth, resulting in micro-yielding of the material [35]. The difference in the onset of plastic deformation measured by the two tee-rosettes at the iris, $180^{\circ}$ apart, is indicative of non-uniform mechanical properties.

Large frequency shift and residual strain (compressive in the longitudinal direction, tensile in the azimuthal one) at both iris locations can be seen in Fig. 13 after a relative pressure of $\sim 276 \mathrm{kPa}$ 
was applied. Plastic deformation can be deduced from the residual strain at the equator region as well, after a pressure of $\sim 414 \mathrm{kPa}$ was relieved.

A plot of the frequency shift as a function of relative pressure measured for the single-cell cavities is shown in Fig. 14.
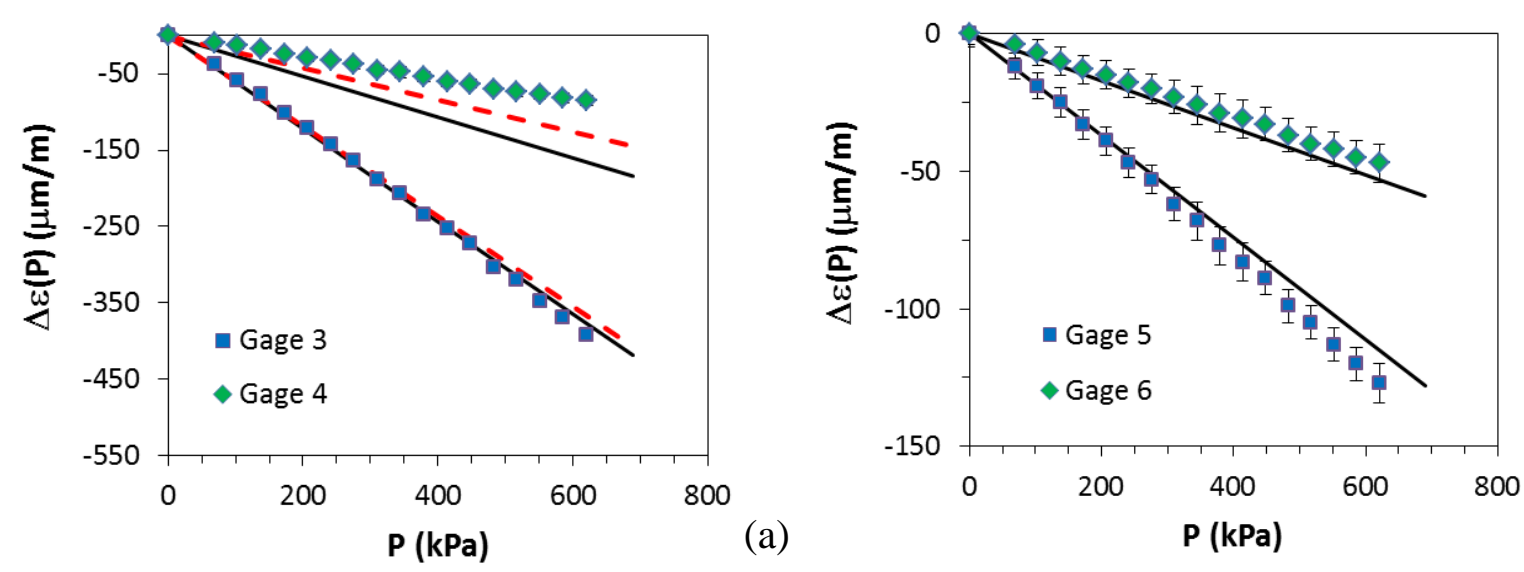

(b)

Fig. 10. Strain versus pressure measured at the iris (gage 3 measures strain in the azimuthal direction, gage 4 in the longitudinal one) (a) and equator (gages 5 and 6 measure strain in the longitudinal direction) (b) regions of fine-grain $\mathrm{Nb}$ single-cell cavity FG after $600{ }^{\circ} \mathrm{C} / 10 \mathrm{~h}$ heat treatment. Solid and dashed lines are results from FEA with $E=88.5 \mathrm{GPa}, v=0.4$ and $v=0.45$ respectively. The error bars in (a) are of the size of the symbols.
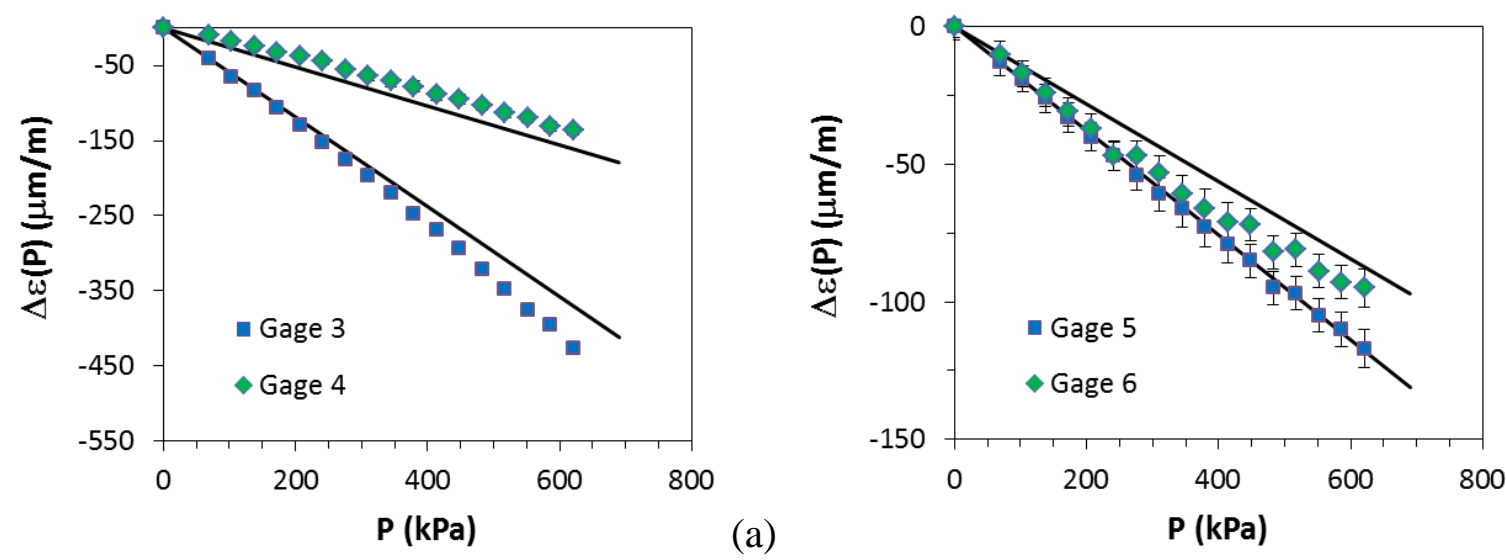

(b)

Fig. 11. Strain versus pressure measured at the iris (gage 3 measures strain in the azimuthal direction, gage 4 in the longitudinal one) (a) and equator (gages 5 and 6 measure strain in the longitudinal direction) (b) regions of fine-grain $\mathrm{Nb}$ single-cell cavity FG after $800{ }^{\circ} \mathrm{C} / 2 \mathrm{~h}$ heat treatment. Solid lines are results from FEA with $E=88.5 \mathrm{GPa}, v=0.4$. The error bars in (a) are of the size of the symbols. 


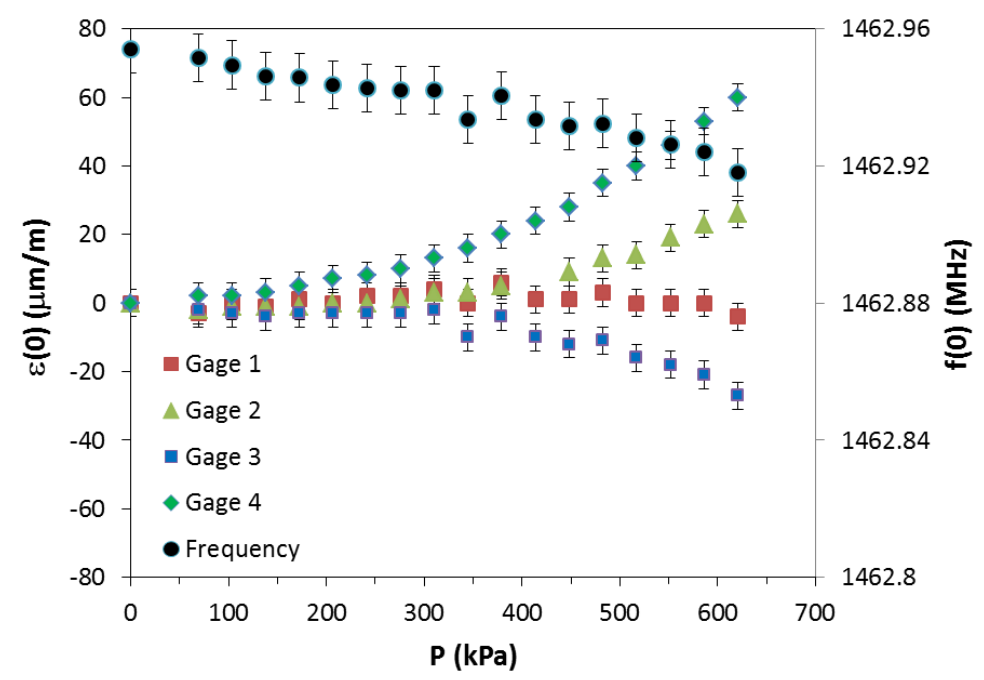

Fig. 12. Strain in the iris region and resonant frequency measured after relieving a uniform pressure applied to the fine-grain cavity FG after $600{ }^{\circ} \mathrm{C} / 10 \mathrm{~h}$ heat treatment.

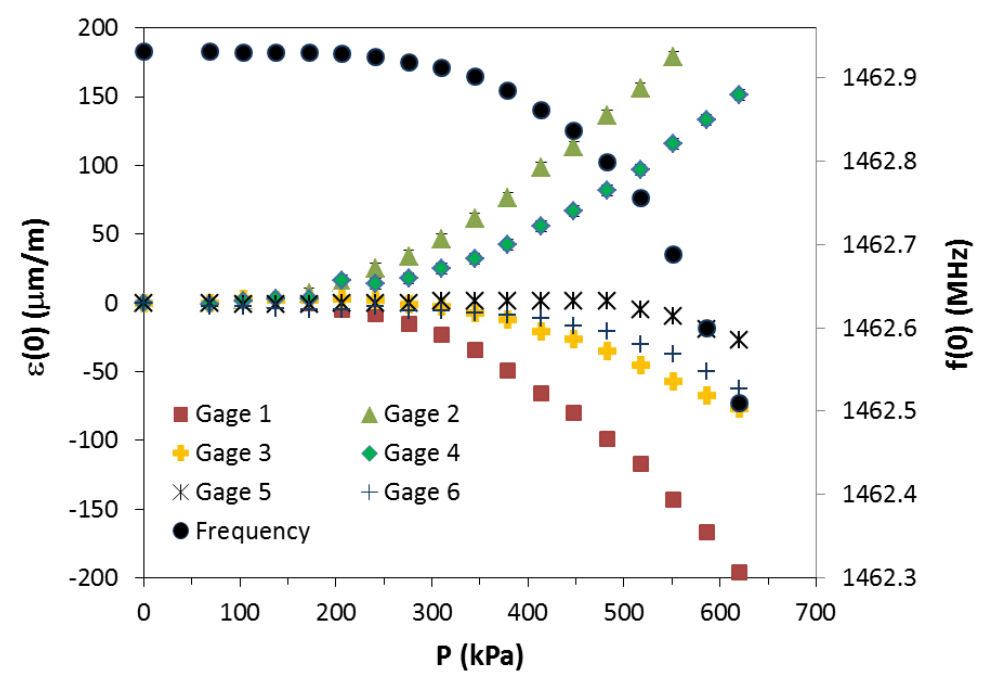

Fig. 13. Strain in the iris (gages 1-4) and equator (gages 5 and 6) regions and resonant frequency measured after relieving a uniform pressure applied to the fine-grain cavity FG after $800{ }^{\circ} \mathrm{C} / 2 \mathrm{~h}$ heat treatment. 


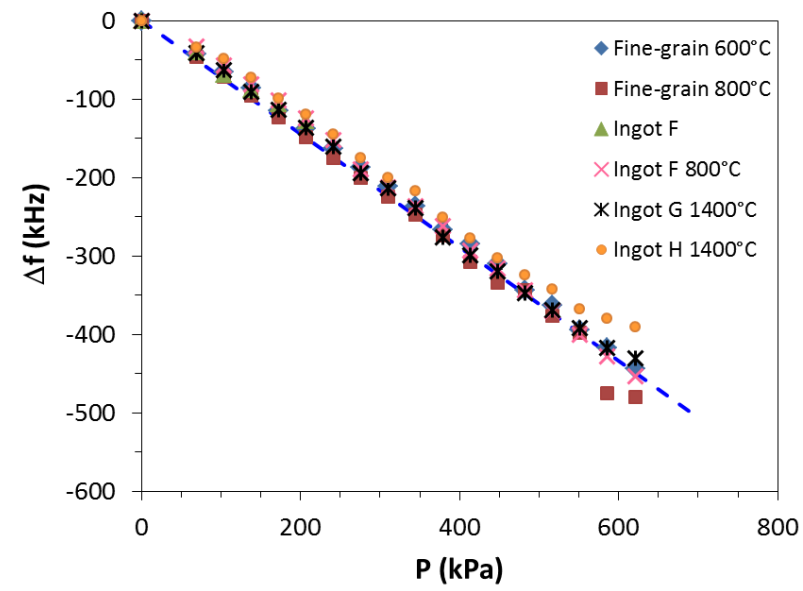

Fig. 14. Change in resonance frequency as a function of relative pressure measured for the single-cell cavities. The solid line is the result from FEA with $E=88.5 \mathrm{GPa}, v=0.4, d=2.8 \mathrm{~mm}$.

The strain and frequency at zero relative pressure as a function of the relieved pressure for ingot $\mathrm{Nb}$ single-cell G1G2 after a highest heat treatment temperature of $1400{ }^{\circ} \mathrm{C}$ are shown in Fig. 15 and indicate plastic deformation at the iris above $\sim 448 \mathrm{kPa}$. Very similar results were obtained on ingot $\mathrm{Nb}$ cavity $\mathrm{H} 1 \mathrm{H} 2$, also heat treated up to $1400{ }^{\circ} \mathrm{C}$. The similarity of the results between single-cells $\mathrm{H} 1 \mathrm{H} 2$ and $\mathrm{G} 1 \mathrm{G} 2$, in spite of G1G2 having been heat-treated multiple times at temperatures between $800{ }^{\circ} \mathrm{C}$ and $1400{ }^{\circ} \mathrm{C}$ suggests that the highest heat-treatment temperature has the most influence on the mechanical properties of the material, which is expected.

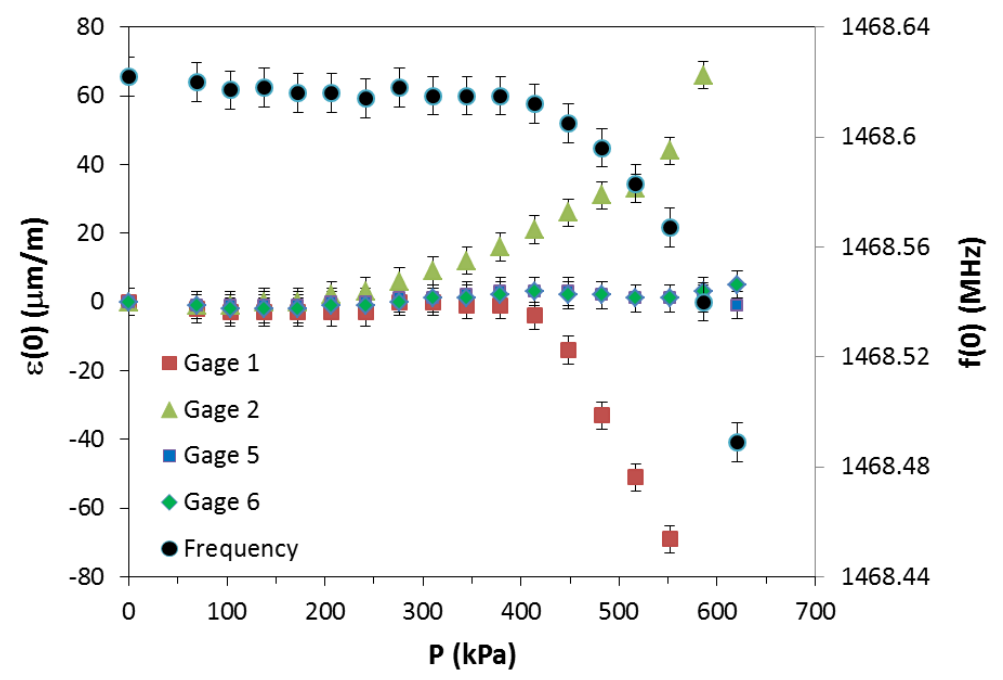

Fig. 15. Strain in the iris (gages 1 and 2) and equator (gages 5 and 6) regions and resonant frequency measured after relieving a uniform relative pressure applied to the ingot $\mathrm{Nb}$ cavity $\mathrm{G} 1 \mathrm{G} 2$ heat treated at a highest temperature of $1400{ }^{\circ} \mathrm{C}$. 
Table 2 provides a summary of the yield pressure, peak von-Mises stress at yield pressure calculated by FEA, $\mathrm{Nb}$ yield strength values for different material and treatment, measured and calculated pressure sensitivities, $\Delta f / \Delta P$. The yield pressure was determined from the point of intersection between linear fits of $f(0)$ vs. $P$ below $200 \mathrm{kPa}$ and above $500 \mathrm{kPa}$ and can be considered as the macro-yield limit.

Table 2. Highest heat treatment temperature, estimated yield pressure and yield strength compared with literature values, measured pressure sensitivity and pressure sensitivity from FEA.

\begin{tabular}{lllllll}
\hline $\begin{array}{l}\text { Cavity } \\
\text { Label }\end{array}$ & $\begin{array}{l}\text { Highest heat- } \\
\text { treatment } \\
\text { temperature } \\
\left({ }^{\circ} \mathrm{C}\right)\end{array}$ & $\begin{array}{l}\text { Yield } \\
\text { pressure } \\
(\mathrm{kPa})\end{array}$ & $\begin{array}{l}\text { Peak von-Mises } \\
\text { stress at yield } \\
\text { pressure from } \\
\text { FEA }(\mathrm{MPa})\end{array}$ & $\begin{array}{l}\text { Yield strength } \\
\text { from literature } \\
(\mathrm{MPa})\end{array}$ & $\begin{array}{l}\text { Measured } \\
\Delta f / \Delta P \\
(\mathrm{~Hz} / \mathrm{Pa})\end{array}$ & $\begin{array}{l}\Delta f / \Delta P \\
\text { from FEA } \\
(\mathrm{Hz} / \mathrm{Pa})\end{array}$ \\
\hline FG & 600 & $>620^{\mathrm{a}}$ & $>52$ & $48-72[9]$ & $-0.70 \pm 0.01$ & -0.72 \\
FG & 800 & 459 & 39 & $38-45[9]$ & $-0.75 \pm 0.04$ & -0.72 \\
F3F4 & - & $>620$ & $>46$ & $30-40[19]$ & $-0.66 \pm 0.02$ & -0.67 \\
F3F4 & 800 & $>620$ & $>48$ & $n / a$ & $-0.72 \pm 0.02$ & -0.70 \\
G1G2 & 1400 & 517 & 40 & $56[36]$ & $-0.72 \pm 0.01$ & -0.67 \\
H1H2 & 1400 & 503 & 40 & $56[36]$ & $-0.68 \pm 0.01$ & -0.70 \\
\hline
\end{tabular}

${ }^{a}$ Fig. 12 show evidence of micro-yielding.

\subsection{Nine-cell cavities}

During the pressurization of the fine-grain 9-cell cavity, noise could be heard when increasing the relative pressure above $700 \mathrm{kPa}$. A loud crack and deformation of a section of cell No. 3 occurred at $1.1 \mathrm{MPa}$. The bellows began deforming plastically above $1.7 \mathrm{MPa}$. At $3.1 \mathrm{MPa}$ the pressure dropped down to $1.7 \mathrm{MPa}$. The antennae and dial gages were removed to look inside the cavity while increasing the pressure. As the pressure rose, cell No. 3 cave inward until it broke upon reaching a pressure of $2.5 \mathrm{MPa}$.

During the test of the ingot $\mathrm{Nb}$ 9-cell cavity, the bellows began deforming plastically above 1.8 $\mathrm{MPa}$. Water entered into the cavity upon reaching 2.2 MPa. After cutting the He-vessels from both 9-cell cavities, deformation was visible in more cells of the ingot $\mathrm{Nb}$ compared to the finegrain cavity. Fig. 16 shows pictures of the cell where the breakage occurred in both cavities: at the stiffening ring location in cell No. 6 of the ingot Nb cavity and at the iris of cell No. 3 of the fine-grain cavity [37].

The change of resonant frequency, relative to the value at zero relative pressure, measured after each pressure step, as a function of relative pressure was $\sim 0.34 \mathrm{~Hz} / \mathrm{Pa}$ for the fine-grain cavity. Not enough data were measured for the ingot $\mathrm{Nb}$ cavity. The frequency increases with increasing 
pressure as the cavity stretches inside the He-vessel, unlike the single-cell cavities which are compressed by the external pressure applied to the whole surface of the cavity. Fig. 17 shows the change in resonant frequency and overall cavity length, $\Delta L$, relative to the initial values at zero pressure, as a function of the relative pressure for both cavities. Fig. 18 shows the frequency and overall length change after relieving the applied relative pressure $P$ to the fine-grain cavity. The onset of plastic deformation, obtained from the intersection of linear fits of the data at low and high pressure, is $\sim 1.1 \mathrm{MPa}$. Not enough data were measured during the test of the ingot $\mathrm{Nb}$ cavity to determine the onset of plastic deformation. Nevertheless, pressure tests of nine 9-cell ingot $\mathrm{Nb}$ cavities up to $580 \mathrm{kPa}$ showed no evidence of plastic deformation and the yielding pressure of the high-purity ingot $\mathrm{Nb}$ cavity can therefore be estimated to be between $0.58 \mathrm{MPa}$ and $\sim 1 \mathrm{MPa}$.
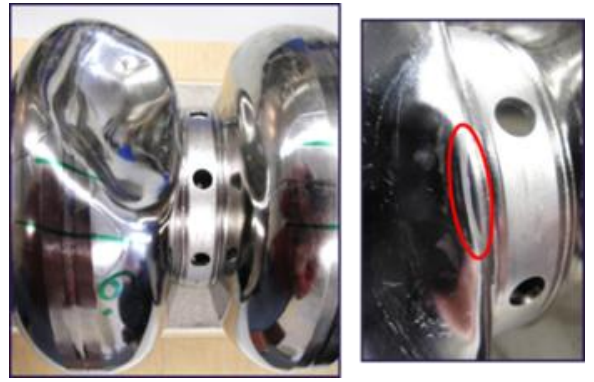

(a)
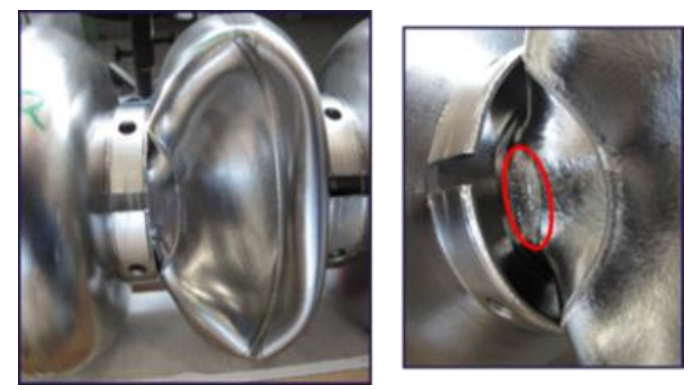

(b)

Fig. 16. Pictures of the deformation and breakage areas on cell No. 6 of the 9-cell high-purity ingot $\mathrm{Nb}$ cavity (a) and on cell No. 3 of the fine-grain, high-purity $\mathrm{Nb}$ cavity (b) [37].

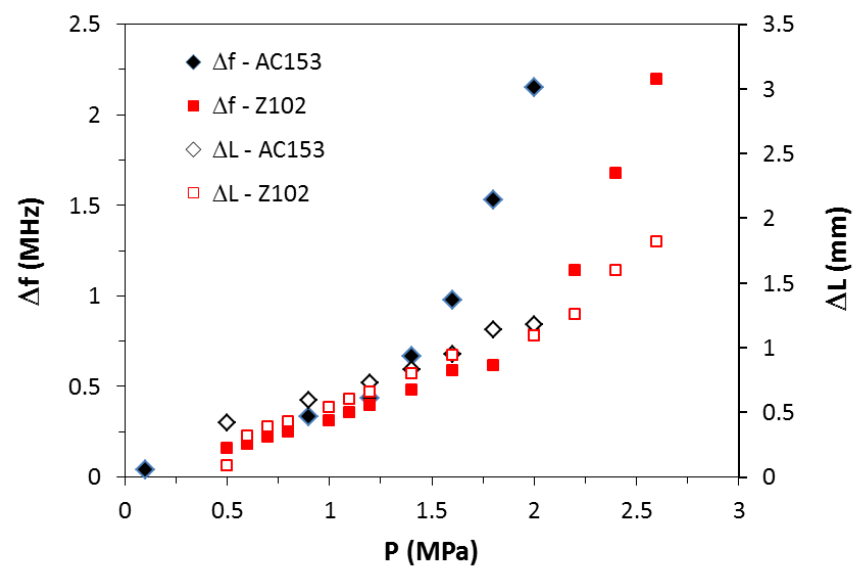

Fig. 17. Changes in cavity frequency and length, relative to the initial value at zero relative pressure, as a function of relative applied pressure for the 9-cell ingot $\mathrm{Nb}$ (AC153) and fine-grain $\mathrm{Nb}(\mathrm{Z102})$ cavities measured during the burst test. 


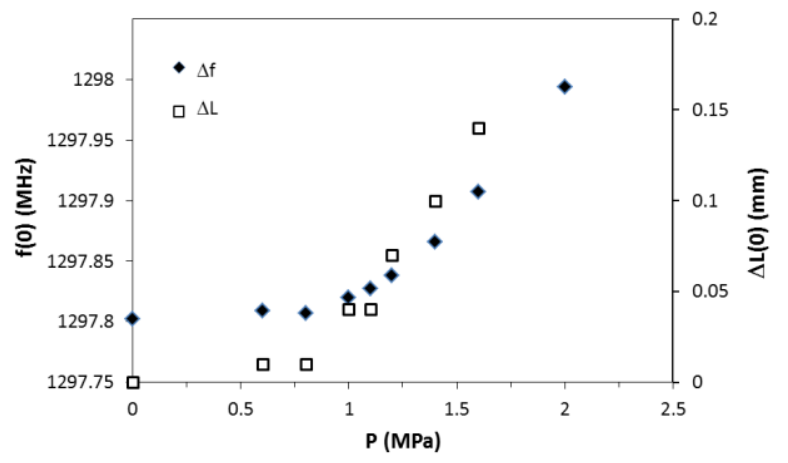

Fig. 18. Frequency and length change measured after relieving the relative pressure $P$ measured for the 9-cell fine-grain $\mathrm{Nb}$ cavity. The yield pressure is $\sim 1.1 \mathrm{MPa}$.

\section{Conclusions}

The results from the pressure tests and finite-element analysis of $\mathrm{Nb}$ single-cell cavities described in the previous sections lead to the following conclusions:

1. The yield strength of fine-grain $\mathrm{Nb}$ is reduced by high-temperature annealing. This effect is well known from sample studies and it is related to grain-growth during annealing. In the case of high-purity $(\mathrm{RRR}>300) \mathrm{Nb}$, a reduction in yield strength is observed already after annealing at $800{ }^{\circ} \mathrm{C} / 2 \mathrm{~h}$. This result is consistent with studies on Nb samples from various vendors which showed, in addition, a significant variation of yield strength from batch to batch and even within the same sheet $[38,39]$. Such variations are correlated with a heterogeneous microstructure resulting from incomplete re-crystallization of the material.

2. The purity of the $\mathrm{Nb}$ has a bigger influence on the yield strength than the grain size. Ingot $\mathrm{Nb}$ cavities of medium-purity (RRR 100) showed a higher yield strength than high-purity fine-grain ones, for the same annealing temperature. Annealing medium purity, ingot $\mathrm{Nb}$ cavities at $1400{ }^{\circ} \mathrm{C}$ resulted in a yield pressure comparable to that of a high-purity, fine-grain $\mathrm{Nb}$ cavity annealed at $800{ }^{\circ} \mathrm{C}$.

3. The yield strength of medium-purity ingot $\mathrm{Nb}$ cavities is affected by the highest annealing temperature, rather than by the heat-treatment history at lower temperatures.

4. Material parameters which resulted in a good agreement between FEA and experiments, regarding the macroscopic elastic behavior of both medium-purity, ingot $\mathrm{Nb}$ and high-purity fine-grain $\mathrm{Nb}$ cavities were $E=88.5 \mathrm{GPa}$ and $v=0.4$. Values of $E$ and $v$ typically found in the literature are between 105-124 GPa and 0.27-0.4 [35, 40-43], respectively. Small discrepancies between FEA results and local strain measured in two orthogonal directions can be related to the uncertainty in the local thickness of the material. No significant change of either Young's modulus or Poisson's ratio was found after annealing. 
5. Burst tests of high-purity fine-grain and ingot $\mathrm{Nb}$ cavities qualified both types of material with respect to pressure vessel regulations, although with less margin for the cavity made of highpurity ingot $\mathrm{Nb}$.

Cryogenic RF tests of 1.3-1.5 GHz medium-purity ingot $\mathrm{Nb}$ cavities demonstrated the achievement of accelerating gradients of $\sim 20 \mathrm{MV} / \mathrm{m}$ [36], when treated by buffered chemical polishing, and up to $30 \mathrm{MV} / \mathrm{m}$, when treated by electropolishing [44], with quality factors greater than $\sim 10^{10}$ at $2 \mathrm{~K}$, therefore satisfying the performance requirement of many current and future accelerators. The results presented in this article demonstrate that the mechanical properties of medium-purity ingot $\mathrm{Nb}$ are superior to those of standard high-purity fine grain $\mathrm{Nb}$, therefore confirming the suitability of such material for the fabrication of SRF cavities to be installed in particle accelerators.

\section{Acknowledgments}

We would like to acknowledge our colleagues from Jefferson Lab: B. Carpenter, J. Henry, P. Kneisel, J. Mammosser, S. Yang and S. Dutton for helping with the work on single-cell cavities and J. Spradlin for the RRR measurements. We would also like to thank H. Roy of MicroMeasurements for many suggestions related to strain gage installation. This manuscript has been authored by Jefferson Science Associates, LLC under U.S. DOE Contract No. DE-AC0506OR23177. The U.S. Government retains a non-exclusive, paid-up, irrevocable, world-wide license to publish or reproduce this manuscript for U.S. Government purposes.

\section{References}

[1] S. Belomestnykh, Rev. Accel. Sci. Tech. 5 (2012) 147-184.

[2] W. Singer, A. Brinkmann, D. Proch, X. Singer, Physica C 386 (2003) 379-384.

[3] P. Kneisel, G. Ciovati, P. Dhakal, K. Saito, W. Singer, X. Singer, G. R. Myneni, Nucl. Inst. Meth. A 774 (2015) 133-150.

[4] A. Reilly, T. Bass, A. Burrill, K. Davis, F. Marhauser, C. E. Reece, M. Stirbet, Proc. of SRF2011, Chicago, IL, USA, 2011, 542-548.

[5] B. van der Horst, A. Matheisen, B. Petersen, M. Schmoekel, N. Steinhau-Kuehl, H. Weitkaemper, Proc. of SRF2009, Berlin, Germany, 2009, 791-793.

[6] G. Cheng, M. Wiseman, Jefferson Lab Technical Note, TN-10-001, 2010.

[7] T. J. Peterson, H. F. Carter, M. H. Foley, A. L. Klebaner, T. H. Nicol, T. M. Page, J. C. Theilacker, R. H. Wands, M. L. Wong-Squires, G. Wu, AIP Conference Proceedings 1218, (2010) 839-848.

[8] C. Astefanous, J. Deacutis, D. Holmes, T. Schultheiss, I. Ben-Zvi, W. Xu, Proc. of PAC2011, New York, NY, USA, 2011, 1322-1324.

[9] G. Cheng, E. F. Daly, Jefferson Lab Technical Note, TN-09-002, 2009.

[10] G. R. Myneni, H. Umezawa, Materiaux \& Techniques, 7-8-9 (2003) 19- 22.

[11] G. R. Myneni, P. Kneisel, Jefferson Lab Technical Note, TN-02-01, 2002.

[12] G. R. Myneni, AIP Conf. Proc. 927 (2007) 41-47.

[13] P. Kneisel, G. R. Myneni, Jefferson Lab Technical Note, TN-88-097, 1988.

[14] P. Kneisel, J. Mammosser, M. G. Rao, K. Saito, Electron Beam Melting and Refining State of the Art, Bakish Materials Corporation, Englewood, 1990, 177-188.

[15] G. R. Myneni, P. Kneisel, Proc. of SRF1993, Newport News, VA, USA, 1993, 643-649. 
[16] L. D. Cooley, Proc. 7th SRF Mater. Workshop, Newport News, VA, USA, 2012. https://www.jlab.org/indico/conferenceDisplay.py?confId=20

[17] T. Gnäupel-Herold, G. R. Myneni, R. E. Ricker, AIP Conf. Proc. 927, (2007) 48-59.

[18] A. Ermakov, I. Jelezov, X. Singer, W. Singer, G. B. Viswanathan, V. Levit, H. L. Fraser, H. Wen, M. Spiwek, J. of Physics: Conference Series 97 (2008) 012014.

[19] T. R. Bieler, N. T. Wright, F. Pourboghrat, C. Compton, K. T. Hartwig, D. Baars, A. Zamiri, S. Chandrasekaran, P. Darbandi, H. Jiang, E. Skoug, S. Balachandran, G. E. Ice, W. Liu, Phys. Rev. ST Accel. Beams 13 (2010) 031002.

[20] G. Wu, N. Dhanaraj, L. Cooley, D. Hicks, E. Hahn, D. Burk, W. Muranyi, M. Foley, H. Edwards, E. Harms, M. Champion, D. Baars, C. Compton, AIP Conf. Proc. 1218 (2010) 857-862.

[21] P. Kneisel, A. Heidt, J. Mammosser, G. R. Myneni, Proc. SRF1991, Hamburg, Germany, 1991, 843-851.

[22] R. Bennett, P. Kneisel, B. Lewis, G. R. Myneni, Jefferson Lab Technical Note, TN-96-006, 1996.

[23] M. Altarelli at el. (eds.), European X-FEL Technical Design Report, DESY 2006-097, 2007. http://xfel.desy.de/technical_information/tdr/tdr/

[24] Pressure Equipment Directive 97/23/EC, May 1997.

[25] P. Kneisel, K. Nakajima, J. Kirchgessner, J. Mioduszewski, IEEE Trans. Nucl. Sci. 30(4), (1983) 3348-3350.

[26] B. Aune et al., Phys. Rev. ST Accel. Beams 3 (2000) 092001.

[27] W. Singer, S. Aderhold, A. Ermakov, J. Iversen, D. Kostin, G. Kreps, A. Matheisen, W.-D. Möller, D. Reschke, X. Singer, K. Twarowski, H. Weise, Phys. Rev. ST Accel. Beams 16 (2013) 012003.

[28] Micro-Measurements, Instruction Bulletin B-129-8 Rev. 19, 2011.

[29] Micro-Measurements, Instruction Bulletin B-127-14 Rev. 14, 2011.

[30] http://ansys.com/

[31] A. Matheisen, H. B. Peters, A. Mosnier, Proc. HEACC'92, Hamburg, Germany, 1992, 960962.

[32] European Union Directive EN 13445-3, Unfired pressure vessels - Part 3: Design, 2002.

[33] TÜV NORD SysTec GmbH \& Co. KG, FEM-strength analysis of the X-FEL Cavity at DESY, Inspection Report 8106740323, 2010.

[34] W. Montero, R. Farag, V. Diaz, M. Ramirez, B. L. Boada, J. Strain Anal. 46 (2011) 1-13.

[35] G. R. Myneni, S. R. Agnew, AIP Conf. Proc. 671 (2003) 227-239.

[36] P. Dhakal, G. Ciovati, G. R. Myneni, K. E. Gray, N. Groll, P. Maheshwari, D. M. McRae, R. Pike, T. Proslier, F. Stevie, R. P. Walsh, Q. Yang, and J. Zasadzinzki, Phys. Rev. ST Accel. Beams 16 (2013) 042001.

[37] A. Schmidt, J. Iversen, A. Matheisen, W. Singer, Proc. SRF2013, Paris, France, 2013, 227 229.

[38] H. Jiang, D. Baars, A. Zamiri, T.R. Bieler, P. Bauer, C. Compton, T.L. Grimm, IEEE Trans. Appl. Supercon. 17 (2007) 1291-1294.

[39] A. Zamiri, F. Pourboghrat, H. Jiang, T.R. Bieler, F. Barlat, J. Brem, C. Compton, T.L. Grimm, Mat. Sci. Eng. A 435-436 (2006) 658-665.

[40] A. Butch, Pure Metals Properties: A Scientific-Technical Handbook, ASM Intern., Materials Park, OH, 1999, p. 155.

[41] J. R. Davis (ed.), Tensile Testing, ASM Intern., Materials Park, OH, 2004, p. 98. 
[42] R. T. Webster, Refractory Metals and Their Industrial Applications, R. E. Smallwood (ed.), ASTM STP 849, 1984, p. 20.

[43] M. Mukhopadhyay, Fundamental of Cryogenic Engineering, PHI Learning, New Delhi, 2010.

[44] P. Dhakal, G. Ciovati, G. R. Myneni, to be published. 